\title{
Overweight or Obesity prevalence, trends and risk factors among women in Rwan- da: A cross-sectional study using the Rwanda Demographic and Health Surveys, 2000-2010
}

\author{
Assumpta Mukabutera ${ }^{1 *}$, Etienne Nsereko², Uwase Aline², Yves Didier Umwungerimwiza², Munyanshongore Cyprien¹ \\ ${ }^{1}$ College of Medicine and Health Sciences, School of Public Health, University of Rwanda \\ ${ }^{2}$ College of Medicine and Health Sciences, School of Health Sciences, University of Rwanda
}

\begin{abstract}
Objectives: Obesity has been a growing concern worldwide and in sub-Saharan Africa in particular. The objective of this study was to explore the prevalence of and secular trends in the rate of being overweight/obese in Rwandan women and the associated socio-demographic risk factors. Design: The study involved a secondary analysis of data from the Rwanda Demographic and Health Surveys (RDHSs) conducted in 2000, 2005 and 2010. These are countrywide, cross-sectional household studies conducted every five years. A stratified cluster sampling technique was used. Setting: A total of 10,421 women in 2000, 11,539 in 2005 and 12,540 in 2010 participated in the population based household surveys in Rwanda. Primary outcome measure: Participants whose body mass indexes were $\geq 25 \mathrm{~kg} / \mathrm{m} 2$ were considered to be overweight/obese. Results: The prevalence of woman being overweight/obese increased from 13\% in 2000 to $16.5 \%$ in 2010. The highest prevalence rates in 2010 were found in Kigali city (35\%) and other urban areas (31.5\%). Women with higher levels of education and from wealthier households were more likely to be overweight/obese. Using multivariable logistic regression analysis in the full model, the area of residence, wealth, religion and the number of household members were found to be significantly associated with being overweight/obese. In the adjusted model only the first three of these were still associated with a significantly increased risk. Conclusion: Being overweight/obese is becoming more common in Rwandan women, especially in those living in urban areas who are wealthy. Being overweight/obese is also associated with being Protestant. The reasons for this association are likely to be complex and require further study. Health awareness campaigns should recognise the importance of over-nutrition, as well as under-nutrition, and should promote healthy diets and the importance of physical activity.
\end{abstract}

Key words: overweight, obesity, women, Rwanda

\section{Introduction}

Obesity in those of childbearing age has became a public health concern worldwide, including low and middle income countries (Kanter \& Caballero, 2012). The World Health Organization (WHO) has estimated that there are 1.4 billion people aged 20 years or older who are overweight, and that almost 300 million of these are women (WHO, 2014) in low and middle income countries, where under-nutrition is endemic, obesity is not usually considered to be a public health priority. However, changes in demography mean that the rates of both being overweight and obesity are increasing in low and middle-income countries.

Being overweight or obese is associated with an increased risk of various non-communicable diseases in both men and women (Webber et al., 2014), threatening healthcare systems that are already overburdened by communicable diseases in developing countries (Boutayeb, 2006). In women of childbearing age, obesity and a tendency to be overweight are associated with polycystic ovarian syndrome, which can lead to reproductive dysfunction (Moran, Dodd, Nisenblat, \& Norman, 2011) .

Food insecurity in Rwanda, as in other developing countries, is a major concern, leading to a focus on under-nutrition. However, recently the efforts of the Rwandan Government have shifted the country from being a poor country towards being a middle-income country. This has been followed by an increase in those who are overweight or obese (Ministry of Health, 2011). However, little is known regarding the rate of the increase or of the causative factors. Understanding the effects of demographic transitions on the body weight of Rwandan women is important for planning and developing evidence-based health policies. The aim of this study was to examine secular trends in the prevalence of being overweight or obese amongst Rwandan women of childbearing age and to identify the socio-demographic factors impacting on it.

\section{Methods}

\section{Data source}

The study involved a secondary analysis of the data from the Rwanda Demographic and Health Surveys (RDHSs) 2000 2005 and 2010. The RDHSs were started in 1992 and are population based, cross-sectional household surveys. They are conducted every five years on nationally representative samples from the households surveyed comprising women aged 15-49 years, men aged $15-59$ years and children. The data collected includes information on the health of women and children, including the nutritional status. The present study used the data collected in the surveys conducted between 2000 and 2010 on the heights and weights of women aged 15-49 years. Only the data from the 2010 survey was used to examine risk factors for being overweight/obese.

\section{Study population and sample size}

The RDHSs use a multi-stage, stratified sampling method. Firstly, villages (also known as clusters or enumeration areas) are selected, with the probability proportional to the village size. Subsequently, a complete mapping and listing of all the households in the selected villages is conducted. This serves as the sampling frame for the selection of the households to be surveyed. The 2000, 2005 and 2010 surveys included 10,421; 11,539 and 12,540 women, respectively.

For all three years anthropometric measurements were obtained from every woman included in the study. 


\section{Outcome measures}

Anthropometric data collected in the surveys was used to calculate the body mass indexes (BMIs) of the participants. $\mathrm{BMI}$ was considered to be a continuous variable. It was categorised according to $\mathrm{WHO}$ recommendations as follows: underweight, $<18.5 \mathrm{~kg} / \mathrm{m} 2$; normal weight, 18.5 $24.9 \mathrm{~kg} / \mathrm{m} 2$; overweight, $25.0-29.9 \mathrm{~kg} / \mathrm{m} 2$; and obese, $\geq 30.0 \mathrm{~kg} / \mathrm{m} 2$. The last two categories were considered together as overweight/obese.

\section{Predictors}

The covariates in this study included age, province, residence educational level, religion, number of household members, number of children of 5 years and under, tobacco use, marital status and current breastfeeding status. Wealth index was developed on the basis of de jure population asset data using principal components analysis.

\section{Statistical analysis}

A univariate analysis was performed to determine summary statistics of selected variables. The prevalence and trends of being overweight/obese by area of residence and stratified by year were described. Chi-square tests were used to assess the associations between being overweight/obese and socioeconomic and demographic factors. After bivariate analysis, we retained for consideration in a multivariable model the variables associated with being overweight/obese with $P$ values $<0.1$. We included all potential predictors in the full model and removed them using backward-stepwise regression, retaining those that were significant at a level of $\mathrm{P}<0.05$.

The analysis was carried out using the STATA statistical software package (StataCorp. 2007. Stata Statistical Software: Release 13. StataCorp LP, College Station, TX, USA), using survey commands to account for the complex sample design. Probability weights were applied to all observations to account for oversampling of urban Primary Sampling Units (PSUs), and confidence intervals accounted for clustering and stratification. The significant level was set at $\mathrm{P}<0.05$, with $95 \%$ confidence intervals $(\mathrm{Cl})$.

\section{Ethical issues}

Approval to access the database was obtained through online registration to DHS Macro. The data were treated as confidential, with no efforts being made to track back individual participants.
The Rwanda National Ethics Committee and the National Institute of Statistics approve the RDHSs

\section{Results}

The prevalence of being overweight/obese increased between 2000 and 2010, both in urban and rural areas (Fig.1). Nationally, it was 13\%, 12\% and $16.5 \%$ in 2000 , 2005 and 2010, respectively. It was particularly high in urban areas such as Kigali.

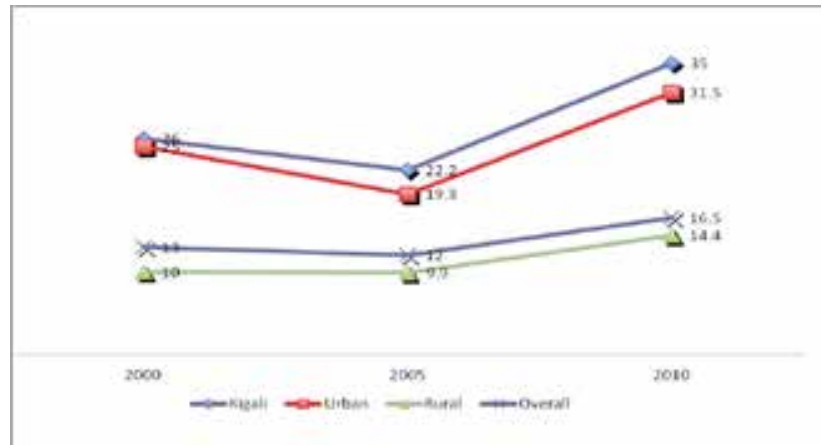

Figure 1. Prevalence and trends of being overweight/ obese among Rwandan women, 2000-2010

Detailed socioeconomic, demographic and other data regarding the participants in the 2010 survey are given in Table 1. Of the 4179 women included, 44\% had given birth to four or more children, $88 \%$ lived in rural areas and $71 \%$ were under 35 years old. With regards to education, $19 \%$ had received no formal education, $72 \%$ had completed primary school and $9 \%$ had completed secondary school. A majority (82\%) were Christians (such as protestant, catholic, Adventist,); nearly all of the remainder were Muslims. Most (85\%) were married and almost half (49\%) used modern contraceptive methods. Most (79\%) were employed, including self-employment. 
Table 1. Socioeconomic, demographic and household characteristics of participants $(N=4179)$

\begin{tabular}{|c|c|c|c|c|c|}
\hline Variables & $\mathrm{n}$ & $\%$ & Variables & $\mathrm{n}$ & $\%$ \\
\hline \multicolumn{3}{|l|}{ Age } & \multicolumn{3}{|l|}{ Number of children ever born } \\
\hline $15-24$ & 754 & 18.04 & One & 642 & 15.36 \\
\hline $25-34$ & 2230 & 53.36 & Two & 862 & 20.63 \\
\hline $35-49$ & 1195 & 28.60 & Three & 716 & 17.13 \\
\hline Total & 4179 & & Four & 553 & 13.23 \\
\hline \multicolumn{3}{|l|}{ Province } & Five & 1406 & 33.64 \\
\hline Kigali city & 389 & 9.31 & Total & 4179 & \\
\hline South & 1013 & 24.24 & \multicolumn{3}{|l|}{ Contraceptive use } \\
\hline West & 1024 & 24.50 & No modern contraceptive & 2123 & 50.79 \\
\hline North & 691 & 16.54 & Modern contraceptive & 2056 & 49.21 \\
\hline East & 1062 & 25.41 & Total & 4180 & \\
\hline Total & 4179 & & Currently breastfeeding & & \\
\hline \multicolumn{3}{|l|}{ Residence } & No & 952 & 22.78 \\
\hline Urban & 499 & 11.94 & Yes & 3227 & 77.22 \\
\hline Rural & 3680 & 88.06 & Total & 4179 & \\
\hline Total & 4179 & & \multicolumn{3}{|l|}{ Marital/Relationship status } \\
\hline \multicolumn{3}{|l|}{ Educational level of mother } & Single & 263 & 6.29 \\
\hline No education & 799 & 19.11 & Married & 3541 & 84.71 \\
\hline Primary & 3004 & 71.89 & Not in union & 375 & 9.00 \\
\hline Secondary and Higher & 376 & 9.00 & Total & 4179 & \\
\hline Total & 4179 & & Tobacco use & & \\
\hline \multicolumn{3}{|l|}{ Religion } & Nil & 3973 & 95.07 \\
\hline Catholic & 1715 & 41.10 & Cigarettes & 13 & 0.31 \\
\hline Protestant & 1688 & 40.45 & Pipe & 36 & 0.86 \\
\hline Adventist & 631 & 15.12 & Chewing & 94 & 2.25 \\
\hline Muslim & 55 & 1.32 & Snuff & 63 & 1.51 \\
\hline \multirow{2}{*}{$\begin{array}{l}\text { Others, including no religion } \\
\text { and Jehovah's witnesses }\end{array}$} & \multirow{2}{*}{84} & \multirow{2}{*}{2.01} & Total & 4179 & \\
\hline & & & Employment & & \\
\hline Total & 4173 & & No & 878 & 21.02 \\
\hline \multicolumn{3}{|l|}{$\begin{array}{l}\text { Number of household } \\
\text { members }\end{array}$} & Yes & 3298 & 78.98 \\
\hline 0-4 members & 657 & 15.72 & Total & 4176 & \\
\hline
\end{tabular}

4+ members $\quad 3522 \quad 84.28$

Total $\quad 4179$

Number of children 5 years old and younger in household

$\begin{array}{lll}\text { O-2 children } & 3645 & 87.22 \\ 3+\text { children } & 534 & 12.78 \\ \text { Total } & 4179 & \end{array}$

The relationships between being overweight/obese and socioeconomic and demographic variables are shown in Table 2. Being overweight or obese was most common in the following groups: those aged 25-34 years; Protestants; those with three or more children; those without a partner; and non-breastfeeding. In addition, being overweight/ obese tended to increase with increasing wealth.

Wealth index

$\begin{array}{lll}\text { Poorest } & 936 & 22.39 \\ \text { Poorer } & 923 & 22.08 \\ \text { Middle } & 852 & 20.41 \\ \text { Richer } & 795 & 19.02 \\ \text { Richest } & 673 & 16.10 \\ \text { Total } & 4179 & \end{array}$


Table 2. Proportion of women who are overweight/obese (BMI > $25 \mathrm{~kg} / \mathrm{m} 2)$ by background characteristics of participants $(n=4179)$

\begin{tabular}{|c|c|c|c|c|c|}
\hline Variable & $\mathrm{N}$ & $\begin{array}{l}\text { No. overweight/obese } \\
\mathrm{n}\end{array}$ & $\begin{array}{l}\text { overweight/obese } \\
\%\end{array}$ & $95 \% \mathrm{Cl}$ & $\mathrm{P}$ value \\
\hline Overall & 4179 & 688 & 16.5 & & \\
\hline \multicolumn{6}{|l|}{ Woman's age } \\
\hline $15-24$ & 754 & 123 & 16.3 & $13.4-19.7$ & 0.396 \\
\hline $25-34$ & 2230 & 385 & 17.3 & $15.1-9.7$ & \\
\hline $35-49$ & 1195 & 179 & 15 & $12.7-17.7$ & \\
\hline \multicolumn{6}{|l|}{ Province } \\
\hline Kigali city & 389 & 136 & 35 & $29.6-40.7$ & 0.000 \\
\hline South & 1013 & 105 & 10.4 & $8.2-13.1$ & \\
\hline West & 1024 & 153 & 14.9 & $12.0-18.5$ & \\
\hline North & 691 & 106 & 15.3 & $11.7-19.8$ & \\
\hline East & 1062 & 187 & 17.6 & $14.8-20.8$ & \\
\hline \multicolumn{6}{|l|}{ Residence } \\
\hline Urban & 499 & 157 & 31.5 & $26.9-36.5$ & 0.000 \\
\hline Rural & 3680 & 530 & 14.4 & $12.9-16.1$ & \\
\hline \multicolumn{6}{|l|}{ Mother's education } \\
\hline No education & 799 & 122 & 15.2 & $12.1-18.9$ & 0.000 \\
\hline Primary & 3005 & 449 & 14.9 & $13.3-16.7$ & \\
\hline Secondary and Higher & 376 & 117 & 31.3 & $25.8-37.3$ & \\
\hline \multicolumn{6}{|l|}{ Religion of woman } \\
\hline Catholic & 1715 & 240 & 14 & $11.9-16.4$ & 0.045 \\
\hline Protestant & 1688 & 315 & 18.6 & $16.2-21.3$ & \\
\hline Adventist & 631 & 104 & 16.5 & $13.1-20.6$ & \\
\hline Muslim & 55 & 14 & 25.1 & $14.9-39.1$ & \\
\hline Others: no religion and Jehovah & 84 & 15 & 18.1 & $9.3-32.2$ & \\
\hline \multicolumn{6}{|l|}{ Number of household members } \\
\hline 0-4 members & 657 & 82 & 12.5 & $9.6-16.3$ & 0.026 \\
\hline $4+$ members & 3522 & 605 & 17.2 & $5.6-18.9$ & \\
\hline \multicolumn{6}{|c|}{ Number of children 5 years and under in household } \\
\hline $0-2$ children & 3645 & 577 & 15.8 & $14.4-17.4$ & 0.111 \\
\hline $3+$ children & 534 & 110 & 20.6 & $15.1-27.6$ & \\
\hline \multicolumn{6}{|l|}{ Wealth index } \\
\hline Poorest & 936 & 94 & 10.1 & $1.5-13.3$ & 0.000 \\
\hline Poorer & 923 & 97 & 10.5 & $8.1-13.4$ & \\
\hline Middle & 853 & 118 & 13.8 & $10.9-17.5$ & \\
\hline Richer & 795 & 153 & 19.2 & $15.8-23.2$ & \\
\hline Richest & 673 & 226 & 33.6 & $29.5-37.9$ & \\
\hline \multicolumn{6}{|l|}{ Number of children ever born } \\
\hline One & 642 & 98 & 15.2 & $12.5-18.5$ & 0.865 \\
\hline Two & 862 & 151 & 17.5 & $14.2-21.3$ & \\
\hline Three & 716 & 110 & 15.3 & $11.7-19.9$ & \\
\hline Four & 553 & 90 & 16.2 & $12.3-21.2$ & \\
\hline Five & 1406 & 240 & 17.1 & $14.4-20.1$ & \\
\hline
\end{tabular}


Table 2. Proportion of women who are overweight/obese (BMI > $25 \mathrm{~kg} / \mathrm{m} 2)$ by background characteristics of participants $(\mathrm{n}=4179)$ cont'd

\begin{tabular}{|c|c|c|c|c|c|}
\hline Variable & $\mathrm{N}$ & No. overweight/obese & overweight/obese & $95 \% \mathrm{Cl}$ & P value \\
\hline \multicolumn{6}{|l|}{ Current type of contraceptive } \\
\hline No modern contraceptive & 2123 & 340 & 16 & $13.9-18.4$ & \multirow[t]{2}{*}{0.594} \\
\hline Modern contraceptive & 2057 & 347 & 16.9 & $14.9-19.0$ & \\
\hline \multicolumn{6}{|l|}{ Currently breastfeeding } \\
\hline No & 952 & 207 & 21.8 & $18.8-25.1$ & \multirow[t]{2}{*}{0.000} \\
\hline Yes & 3228 & 480 & 14.9 & $13.2-16.8$ & \\
\hline \multicolumn{6}{|l|}{ Marital status } \\
\hline Single & 263 & 40 & 15.1 & $11.0-20.4$ & \multirow[t]{3}{*}{0.418} \\
\hline Married & 3541 & 576 & 16.3 & $14.7-18.0$ & \\
\hline Not in union & 376 & 72 & 19.2 & $14.5-24.9$ & \\
\hline \multicolumn{6}{|l|}{ Tobacco use } \\
\hline Not smoking & 3973 & 658 & 16.6 & $15.0-18.2$ & \multirow[t]{5}{*}{0.793} \\
\hline Cigarette & 13 & 2 & 16.8 & $2.4-62.6$ & \\
\hline Pipe & 36 & 7 & 19.9 & $7.9-42.0$ & \\
\hline Chewing & 94 & 9 & 9.7 & $3.2-26.2$ & \\
\hline Snuff & 63 & 11 & 17 & $8.0-32.4$ & \\
\hline \multicolumn{6}{|l|}{ Employment } \\
\hline No & 878 & 136 & 15.5 & $12.4-19.2$ & \multirow[t]{2}{*}{0.524} \\
\hline Yes & 3298 & 552 & 16.7 & $15.1-18.5$ & \\
\hline
\end{tabular}

The results of the multivariate logistic regression analysis are shown in Table 3. In the full model, the area of residence, wealth, religion and the number of household members were found to be significantly associated with being overweight/ obese. In the adjusted model, only the first three of these were still associated with a significantly increased risk.

Table 3. Multivariable logistic regression analysis of the correlations of being overweight or obese

\begin{tabular}{|c|c|c|c|c|c|c|c|c|}
\hline \multirow[t]{2}{*}{ Variables } & \multicolumn{4}{|c|}{ Full model } & \multicolumn{4}{|c|}{ Adjusted model } \\
\hline & $O R^{a}$ & \multicolumn{2}{|c|}{$95 \% \mathrm{Cl}^{\mathrm{b}}$} & P value & $O R^{a}$ & \multicolumn{2}{|c|}{$95 \% \mathrm{Cl}$} & P value \\
\hline \multicolumn{9}{|l|}{ Woman's age } \\
\hline $15-24$ & 1 & & & & & & & \\
\hline $25-34$ & 1.03 & 0.76 & 1.38 & 0.867 & - & - & - & - \\
\hline $35-49$ & 0.85 & 0.61 & 1.19 & 0.341 & - & - & - & - \\
\hline \multicolumn{9}{|l|}{ Mother's education } \\
\hline No education & 1 & & & & & & & \\
\hline Primary & 0.87 & 0.63 & 1.18 & 0.36 & - & - & - & - \\
\hline Secondary and Higher & 1.16 & 0.77 & 1.76 & 0.475 & - & - & - & - \\
\hline \multicolumn{9}{|l|}{ Province } \\
\hline Kigali city & 1 & & & & & & & \\
\hline South & 0.59 & 0.36 & 0.96 & 0.035 & - & - & - & - \\
\hline West & 0.84 & 0.51 & 1.36 & 0.473 & - & - & - & - \\
\hline North & 0.89 & 0.51 & 1.53 & 0.665 & - & - & - & - \\
\hline East & 0.9 & 0.56 & 1.43 & 0.642 & - & - & - & - \\
\hline \multicolumn{9}{|l|}{ Residence } \\
\hline Urban & 1 & & & & 1 & & & \\
\hline Rural & 0.75 & 0.51 & 1.12 & 0.161 & 0.68 & 0.51 & 0.92 & 0.012 \\
\hline
\end{tabular}


Table 3. Multivariable logistic regression analysis of the correlations of being overweight or obese cont'd

\begin{tabular}{|c|c|c|c|c|c|c|c|c|}
\hline \multicolumn{9}{|l|}{ Wealth index } \\
\hline Poorest & 1 & & & & 1 & & & \\
\hline Poorer & 1.02 & 0.67 & 1.56 & 0.915 & 1.07 & 0.71 & 1.61 & 0.747 \\
\hline Middle & 1.32 & 0.86 & 2.01 & 0.199 & 1.46 & 0.96 & 2.22 & 0.077 \\
\hline Richer & 1.87 & 1.22 & 2.86 & 0.004 & 2.06 & 1.38 & 3.08 & 0.000 \\
\hline Richest & 2.91 & 1.84 & 4.58 & 0.000 & 3.75 & 2.55 & 5.52 & 0.000 \\
\hline \multicolumn{9}{|l|}{ Religion of woman } \\
\hline Catholic & 1 & & & & 1 & & & \\
\hline Protestant & 1.3 & 1 & 1.68 & 0.047 & 1.34 & 1.05 & 1.72 & 0.021 \\
\hline Adventist & 1.13 & 0.8 & 1.6 & 0.497 & 1.16 & 0.82 & 1.65 & 0.386 \\
\hline Muslim & 1.13 & 0.59 & 2.19 & 0.707 & 1.19 & 0.63 & 2.23 & 0.591 \\
\hline Other (no religion and Jehovah) & 1.26 & 0.54 & 2.96 & 0.587 & 1.38 & 0.59 & 3.21 & 0.459 \\
\hline \multicolumn{9}{|l|}{ Number of household members } \\
\hline 0-4 members & 1 & & & & 1 & & & \\
\hline $4+$ members & 1.46 & 1.04 & 2.05 & 0.029 & 1.4 & 0.99 & 1.96 & 0.054 \\
\hline \multicolumn{9}{|l|}{ Currently breastfeeding } \\
\hline No & 1 & & & & & & & \\
\hline Yes & 0.79 & 0.61 & 1.03 & 0.087 & - & - & - & - \\
\hline
\end{tabular}

${ }^{\mathrm{a}} \mathrm{OR}=$ odds ratio, ${ }^{\mathrm{b}} \mathrm{Cl}=$ Confidence Interval

\section{Discussion}

Our study showed that there was an increase in numbers of overweight/obese women in Rwanda in the decade from 2000 to 2010. This was seen in women from both urban and rural areas, although the increase was greater in urban areas where one in three women were overweight or obese.

Currently, problems arising from both under and overnutrition pose challenges to healthcare systems in developing and middle-income countries and are, in part, a consequence of urbanisation, global nutrition transition and lifestyle changes (Puoane et al., 2002; SK Kapoor, 2002) . In Africa, women were disproportionately affected (Puoane et al., 2002). Our findings are concordant with those reported by the Rwanda Ministry of Health in 2011 and may be a consequence of the transition from a low- to a middleincome country (Ministry of Finance, 2012).

Being overweight/obese is a particular problem of wealthier urban women. This may reflect their easy access to calorie rich foods and limited physical exercise. Similar findings have been reported from elsewhere in Africa like in Ghana, Kenya, Niger, Malawi, Senegal and others (Abubakari et al., 2008; Kruger et al., 2012; Puoane et al., 2002; Turi, Christoph, \& Grigsby-Toussaint, 2013) and from Brazil (Alves, Falcão, Pinto, \& Correia, 2011). Wealthier women in urban areas often have household helpers and watch more television which might be limiting their physical activities (Agbeko, 2013)

An interesting finding of our study was the association between being overweight/obese and being Protestant. An association between weight and religion has been reported before(Cline \& Ferraro, 2006). The explanation for it is likely to be complex. Some religions, including Protestant, preach that the use of tobacco products and alcohol is sinful. Food and sugary tea may be substituted. Religious cultural pressures may cause many women to consume sugary drinks rather than alcohol, contributing to obesity, with associated risks to their health (Schulze et al., 2004). Public health interventions, delivered as part of community education, should promote the benefits of healthy diets and regular physical activities (Ettarh, Van de Vijver, Oti, \& Kyobutungi, 2013)

\section{Limitations}

The RDHSs are cross-sectional studies, collecting data at particular points in time. It is not appropriate to infer causation from them. Moreover, data were not collected on physical activity levels, which are known to be an important factor determining individuals' weights.

\section{Conclusions}

This study identified factors associated with being overweight/obese in Rwandan women. We found that the prevalence was highest in those living in urban locations, in those who were wealthy and Protestants. Like under nutrition, over-nutrition should be considered an important health issue. Further studies are required to investigate the link between religious affiliation and weight.

\section{Acknowledgements}

We acknowledge Inner City Fund (ICF) International and Measure evaluation for availing the data used for this analysis.

\section{Conflict of interests}

There are none

\section{Authors' contribution}

AM and EN were responsible for the design of the study and the data analysis. All the authors contributed to the interpretation of the data, the writing and revisions to the manuscript. 


\section{References}

Abubakari, A. R., Lauder, W., Agyemang, C., Jones, M., Kirk, A., \& Bhopal, R. S. (2008). Prevalence and time trends in obesity among adult West African populations: A meta-analysis. Obesity Reviews, 9(4), 297-311. doi:10.1111/j.1467-789X.2007.00462.x

Agbeko, M. P. (2013). Predictors of Overweight and Obesity Among Women in Ghana. Open Obesity, 72-81.

Alves, J. G., Falcão, R. W., Pinto, R. A., \& Correia, J. B. (2011). Obesity patterns among women in a slum area in Brazil. Journal of Health, Population, and Nutrition, 29(3), 286-289.

Boutayeb, A. (2006). The double burden of communicable and non-communicable diseases in developing countries. Transactions of the Royal Society of Tropical Medicine and Hygiene, 100(3), 191 -199. doi:10.1016/j. trstmh.2005.07.021

Cline, K. M. C., \& Ferraro, K. F. (2006). Does religion increase the prevalence and incidence of obesity in adulthood? Journal for the Scientific Study of Religion, 45(2), 269 281. doi:10.1111/j.1468-5906.2006.00305.x

Ettarh, R., Van de Vijver, S., Oti, S., \& Kyobutungi, C. (2013). Overweight, obesity, and perception of body image among slum residents in nairobi, kenya, 2008-2009. Preventing Chronic Disease, 10, E212. doi:10.5888/ pcd10.130198

Kanter, R., \& Caballero, B. (2012). Global Gender Disparities in Obesity: A Review. Advances in Nutrition: An International Review Journal. doi:10.3945/ an.112.002063

Kruger, H. S., Steyn, N. P., Swart, E. C., Maunder, E. M., Nel, J. H., Moeng, L., \& Labadarios, D. (2012). Overweight among children decreased, but obesity prevalence remained high among women in South Africa, 1999-2005. Public Health Nutrition. doi:10.1017/ S136898001100262X

Matthias B. Schulze, DrPH; JoAnn E. Manson, MD; David S. Ludwig, MD; Graham A. Colditz, MD; Meir J. Stampfer, MD; Walter C. Willett, MD; Frank B. Hu, M. (2004). Sugar-Sweetened Beverages, Weight Gain, and Incidence of Type 2 Diabetes in Young and MiddleAged Women. JAMA, 292(8), 927-934. doi:10.1001/ jama.292.8.927

Ministry of Finance, R. of R. (2012). ECONOMIC DEVELOPMENT AND POVERTY REDUCTION STRATEGY , (September 2007), 2008-2012.

MoH. (2011). HEALTH SECTOR SITUATION ANALYSIS 2011. Moran, L. J., Dodd, J., Nisenblat, V., \& Norman, R. J. (2011). Obesity and reproductive dysfunction in women. Endocrinology and Metabolism Clinics of North America, 40(4), 895-906. doi:10.1016/j. ecl.2011.08.006

Puoane, T., Steyn, K., Bradshaw, D., Laubscher, R., Fourie, J., Lambert, V., \& Mbananga, N. (2002). Obesity in South Africa: the South African demographic and health survey. Obesity Research, 10(10), 1038-1048. doi:10.1038/oby.2002.141

SK Kapoor, K. A. (2002). Nutritional transition: a public health challenge in developing countries. CJ Epidemiol Community Health, 74(Suppl II), 2-3. doi:doi:10.136/ jech.56.11.804

Turi, K. N., Christoph, M. J., \& Grigsby-Toussaint, D. S. (2013). Spatial distribution of underweight, overweight and obesity among women and children: results from the 2011 Uganda Demographic and Health Survey. International Journal of Environmental Research and Public Health, 10(10), 4967-81. doi:10.3390/ ijerph10104967

Webber, L., Divajeva, D., Marsh, T., McPherson, K., Brown, M., Galea, G., \& Breda, J. (2014). The future burden of obesity-related diseases in the 53 WHO EuropeanRegion countries and the impact of effective interventions: a modelling study. BMJ Open, 4(7), e004787. doi:10.1136/bmjopen-2014-004787

WHO, W. H. O. (2014). Media centre Obesity and overweight. 